J. Perinat. Med. 15 (1987) 425

\section{Pathway of significance for the synthesis of pulmonary surfactant}

\author{
Goran Enhorning \\ Department of Gynecology and Obstetrics, Children's Hospital of Buffalo, State \\ University of New York at Buffalo, U.S.A.
}

The synthesis of pulmonary surfactant has been thoroughly studied and well-written reviews by BATENburg, Jobe and Jacobs, Possmayer, and SMITH are to be found as chapters in a recently published book [6]. For a discussion of what might influence the synthesis of pulmonary surfactant, there must be an agreement on what constitutes surfactant. Is it the material stored in the lamellar bodies seen in the cytoplasm of alveolar pneumocytes type II or is it the material that has been extruded into the hypophase of the alveolar space and has taken the shape of myelin figures? There can be no argument; surfactant is present in the two locations mentioned, but probably not in pure form. It may be mixed with components that are essential for a transportation from those locations to the air-liquid interface film of the alveoli. Once the film has formed, quite likely, some components have played out their role and are no longer participating. Should a puristic aspect be observed when considering what constitutes surfactant? Only the material forming the film at the airliquid interface should then be considered. That film consists mainly of dipalmitoyl phosphatidylcholine (DPPC), but not exclusively, as seen with the bubble surfactometer (figure 1). When compressed, the film is likely to consists of DPPC only; but, when expanded, other components move in. DPPC can, therefore, be considered as the functionally most important constituent of surfactant and those who have purified and analyzed surfactant with various techniques have all come to the conclusion that DPPC is also quantitatively a major component. In the lung, as opposed to other tissues, for instance the liver, there is a remarkably high percentage of the $\mathrm{PC}$ that is disaturated with palmitic acid.

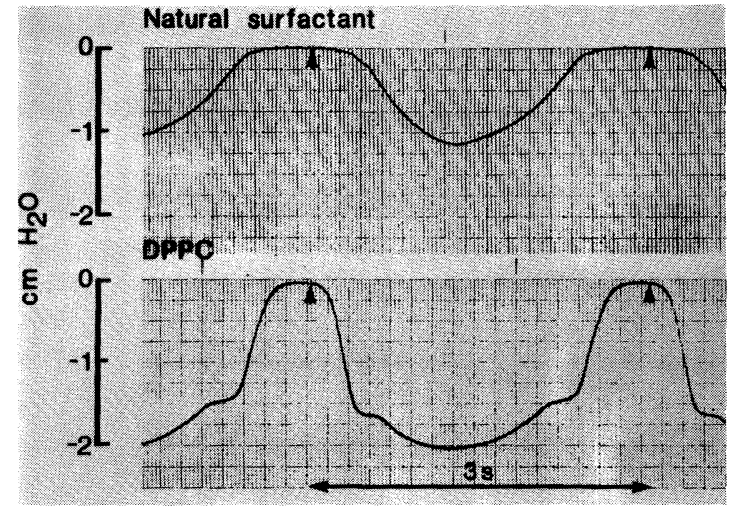

Figure 1. Tracings of natural surfactant and DPPC obtained with a pulsating bubble surfactometer. Pressure is recorded in the liquid surrounding the bubble as it oscillates from maximal $(\mathrm{R}=0.55 \mathrm{~mm})$ to minimal size $(\mathrm{R}=0.4 \mathrm{~mm})$ marked with arrow. Obviously, natural surfactant does not consist of DPPC only.

My review of the synthesis of pulmonary surfactant deals, therefore, with DPPC only. Other forms of PC are synthesized in a similar way and other phospholipids, such as phosphatidyl ethanolamine (PE), phosphatidyl inositol (PI), phosphatidyl glycerol (PG), and phosphatidyl serine (PS) require only moderate modifications of the system of synthesis. We may first consider the origin of the various building blocks: the glycerol backbone, the palmitic acids, the phosphate and the choline. 
Glycerol: The concentration of glycerol in the blood is so low that the lung cannot be sufficiently supplied with ready-made glycerol arriving with the bloodstream, but has to synthesize its own need from glucose which is readily supplied with the blood [6]. However, the glucose may have arrived to the lung at an earlier stage and was stored as glycogen. Just preceding the very active PC synthesis, announcing the fetal lung maturation, is a breakdown of the rich glycogen store that has been gathered in epithelial cells of the fetal lung. It is conceivable that glucose, needed for glycerol and other building blocks of DPPC, originates from that glycogen [1].

Palmitic acids: The fatty acids of DPPC can be synthesized by the lung tissue itself [2], but they can also originate from other sources. When labeled palmitic acid was injected I. V., it was readily incorporated into DPPC of the lung [9]. The exogenous palmitic acid may also result from hydrolysis of tri- or diacyl glycerol in circulating lipoproteins. The necessary enzyme - lipoprotein lipase - is available in the lung [4].

Choline and phosphate: Choline is generously supplied with the bloodstream and is salvaged. The enzyme choline kinase, present in the lungs of several mammals including man, catalyzes the conversion into choline phosphate, the initial step in the synthesis of DPPC. ATP supplies the phosphate when converted to ADP.

The build-up of DPPC: With the catalytic effect of choline phosphate cytidylyltransferase, an enzyme known to be present in the lungs of the human neonate [8], choline phosphate is converted into cytidine diphosphate choline (CDPcholine). The enzyme exists in two forms with high and low molecular weight (the $\mathrm{H}$ and the $\mathrm{L}$ form, respectively). The lung of the rat has been studied. It has been found that the adult animal principally has a more active $\mathrm{H}$ form; whereas, the fetal lung mainly has the relatively inactive $\mathrm{L}$ form. However, this fetal inactive form can be converted to the active $\mathrm{H}$ form by the presence of certain phospholipids, PG being the most important [3]. PG is an amphipathic molecule like DPPC, but its importance may not be its ability to form part of the air-liquid interface film, but to activate one of the enzymes necessary for synthesis of DPPC.

The enzyme choline phosphotransferase is necessary for the next step: the esterification of 1-, 2diacyl-sn-glycerol with the phosphorylcholine of CDPcholine [10]. In most tissues studied, the PC formed according to this CDPcholine pathway has generally an unsaturated fatty acid in the 2position. In the lung, however, there is a high probability that palmitic acid will be in this position. If the saturated fatty acid was not there initially, an unsaturated fatty acid in the 2- position may be removed by the enzymatic effect of phospholipase $\mathrm{A}_{2}$. The palmitic acid may then be supplied as palmitoyl CoA or it may arrive from another molecule of lysoPC, which becomes glycerol phosphocholine when its palmitic acid is given off to form DPPC.

\section{Comment}

Of the enzymes mentioned which are necessary for this the most important pathway of DPPC synthesis, the CDPcholine or salvage pathway, choline phosphate cytidylyltransferase is the most crucial, since it catalyzes the slowest and, thus, rate-limiting reaction. Glucocorticoids, clinically used to accelerate the lungs' maturation process, interfere with the activity of several enzyme systems and are able to stimulate choline phosphate cytidylyltransferase. PG also stimulates the enzyme by converting it into the more active $\mathrm{H}$ form. This may be the reason that, once PG has started to be synthesized and can be detected in amniotic fluid, there is very little risk that RDS will develop after birth, since the PG will help to stimulate the synthesis of DPPC. The increased synthesis of phosphatidylcholine, resulting from stimulation with cortisol, may be inhibited by insulin. This may be one reason why diabetic mothers' infants, who often have developed hyperinsulinemia, are more prone to suffer from RDS.

As mentioned in the introduction, it is evident that a pulmonary surfactant film consists also of other components than DPPC. Once those other components have been identified, a discussion of surfactant synthesis most certainly should include their synthesis. It is not clear if there are such adjunctive components permanently in the film or if they are all mobile; squeezed out and reentering the film as the latter is being compressed and expanded during breathing [5]. Nor is it quite clear what is needed for a quick formation of the film, i.e., for a fast adsorption. There are strong indications, however, that a very low molecular weight protein may have an advantageous effect in this respect. That protein is known to be very hydrophobic and has been designated as a proteolipid [7]. 


\section{Summary}

The most important component of pulmonary surfactant is dipalmitoyl phosphatidylcholine, or DPPC. At the end of an expiration, when the surfactant film is maximally compressed, DPPC is probably almost the sole component in the monomolecular film, but, during inspiration, as the film expands, other elements move in. They may be phospholipids with different fatty acids, saturated or unsaturated, or with the alcohol choline replaced with ethanolamine, inositol, glycerol or serine. The elements moving into the expanding film may also be free fatty acids, di- or triglycerides, etc.

The synthesis of DPPC, similar to that of other phospholipids, has been thoroughly studied and is reviewed.
The building blocks, glycerol, palmitic acid, choline and phosphate, are generally produced in the lung itself, but choline is generously supplied with the bloodstream.

The slowest and, therefore, rate-limiting reaction is conversion of choline phosphate to cytidine diphosphate choline (CDP choline). The enzyme required, choline phosphate cytidyltransferase, is, therefore, crucial. It exists in two forms and can be stimulated to be converted to the more active $\mathrm{H}$-form by the presence of phosphatidylglycerol. This would give $\mathrm{PG}$ a specific role; it has no unique ability to affect the surface tension, but it stimulates the synthesis of DPPC.

Keywords: Bubble surfactometer, choline phosphate cytidylyltransferase, cytidine diphosphate choline, dipalmitoylphosphatidylcholine, phosphatidylglycerol.

\section{Zusammenfassung}

\section{Wichtige Stoffwechselschritte bei der Synthese des Lun- gensurfactant}

Die wichtigste Komponente beim Lungensurfactant ist das Dipalmitoylphosphatidylcholin oder DPPC. Bei maximaler Kompression des Surfactantfilms am Ende der Ausatmung ist das DPPC möglicherweise die einzige Komponente in dem monomolekularen Film, während bei Inspiration und Ausbreitung des Films andere Komponenten hinzukommen. Das können Phospholipide mit unterschiedlichen, teils gesättigten, teils ungesättigten Fettsäuren sein oder mit Äthanolamin, Inositol, Glycerol oder Serin anstelle des Cholins. Auch freie Fettsäuren, Di- oder Triglyceride usw. können Bestandteile des sich ausbreitenden Films sein.
Die Synthese des DPPC ist mit der anderer Phospholipide vergleichbar und wurde gründlich untersucht bzw. hier dargestellt. Die Bausteine - Glycerol, Palmitinsäure, Cholin und Phosphat - werden gewöhnlich in der Lunge selbst produziert, Cholin wird zusätzlich über das Blut herantransportiert.

Die langsamste und damit die Synthese limitierende Reaktion ist die Umwandlung vom Cholinphosphat zum Cytidindiphosphatcholin (CDP-Cholin). Das entscheidende Enzym ist die Cholinphosphatcytidyltransferase. Sie liegt in zwei Formen vor, wobei Phosphatidylglycerol einen Stimulus zur Konversion in die aktivere H-Form darstellt. Damit hat das PG eine spezifische Funktion: es beeinflußt nicht nur die Oberflächenspannung, sondern stimuliert auch die DPPC-Synthese.

Schlüsselwörter: Cholinphosphatidylcytidyltransferase, Cytidindiphosphatcholin, Dipalmitoylphosphatidylcholin, Phosphatidylglycerol, Schaum-Surfactometer.

\section{Résumé}

\section{Pistes de signification de la synthèse du surfactant pulmo-} naire

Le composant le plus important du surfactant pulmonaire est le dipalmitoyl phosphatidylcholine, ou DPPC. A la fin de l'expiration, lorsque le film de surfactant est comprimé au maximum, le DPPC est vraisemblablement l'unique composant du film monomoléculaire, mais en cours d'inspiration, alors que le film s'étend, d'autres éléments prennent place. Ces éléments peuvent être des phospholipides avec différents acides gras aturés ou non, ou avec remplacement de la choline alcool par de l'ethanolamine, de l'inositol, du glycérol ou de la sérine. Les éléments prenant place dans le film en expansion peuvent également être des acides gras libres, des dí- ou des triglycérides, etc.
La synthèse du DPPC analogue à celle des autres phospholipides, a été étudiée à fond et est passée en revue. Les précurseurs - glycérol, acide palmitique, choline et phosphate - sont en règle synthétisés dans le poumon, mais la choline est généreusement fournie par le flux sanguin.

La réaction la plus lente et néanmoins limitante est la conversion le la choline phosphate en cytidine diphosphate choline (CDP choline). L'enzyme nécessaire la choline phosphate cytidylyltransferase est ainsi capitale. Elle existe sous deux formes et peut-être stimulée pour être convertie en forme $\mathrm{H}$ plus active en présence de phosphatidylglycérol. Ce fait donnerait au PG un rôle spécifique; il n'a pas que la capacité unique de jouer sur la tension de surface, mais il stimule la synthèse du DPPC.

Mots-clés: Choline phosphate cytidylyltransferase, cytidine diphosphate choline, dipalmitoylphosphatidylcholine, phosphatidylglycerol, surfactomètre à bulle. 


\section{References}

[1] Bourbon JR, M Rieutort, MJ ENGLe, PM FARRELL: Utilization of glycogen for phospholipid synthesis in fetal rat lung. Biochim Biophys Acta 712 (1982) 382

[2] CHIDA N, FH ADAMS: Incorporation of acetate into fatty acids and lecithin by lung slices of fetal and newborn lambs. J Lipid Res 8 (1967) 335

[3] Feldman DA, CR Kovac, PL Draginis, PA WeinHOLD: The role of phosphatidyl-glycerol in the activation of CTP: phosphocholine cytidylyltransferase from rat lung. J Biol Chem 253 (1978) 4980

[4] HAMOSH M, P HaMosh: Lipoprotein lipase in rat lung - The effect of fasting. Biochim Biophys Acta 380 (1975) 132

[5] NotTER RH, DL SHAPIRO: Lung surfactant in an era of replacement therapy. Pediatrics 68 (1981) 781

[6] ROBERTSON B, LMG VAN GOLDE, JJ BADENBURG (eds): Pulmonary Surfactant. Elsevier, Amsterdam 1985

[7] Takahashi A, T Fujiwara: Proteolipid in bovine lung surfactant: its role in surfactant function. Biochem Biophys Res Commun 135 (1986) 527

[8] Thоm ML, RD Zachman: The enzymes of lecithin biosynthesis in human neonatal lungs. IV. Phosphorylcholine cytidylyltransferase. Pediatr Res 9 (1975) 201

[9] Thomas T, RA ThOADES: Incorporation of palmitate-1-24C into lung tissue and "alveolar" lecithin. Am J Physiol 219 (1870) 1535

[10] ZACHMAN RD: The enzymes of licithin biosynthesis in human newborn lungs. III. Phosphorylcholine glyceride transferase. Pediatr Res 7 (1973) 632

Goran Enhorning, M.D.

State University of New York at Buffalo Department of Gynecology and Obstetrics Children's Hospital of Buffalo 219 Bryant Street Buffalo, New York 14222, U. S. A. 